\title{
Pengaruh Perubahan Pendapatan Bunga Bersih dan Size terhadap Expected Return Saham pada Perusahan Perbankan di BEI Tahun 2006 - 2010
}

\section{The Influences of Changing Net Interest Income and Size to Share Expected Return in Banking Company in BEI 2006 - 2010}

\author{
Harry Budiantoro \\ Program Studi Akuntansi Fakultas Ekonomi Universitas YARSI \\ E-mail: harry.budiantoro@yarsi.ac.id
}

KEYWORDS Expected Return, Net Interest Income, SIZE

ABSTRACT Information content from net interest income and size of entity have very important role to provide information for users to make decision in accordingly. For investor, information in financial statement moght be used to determine the risk rate in expected return. This research aims to testthe influence iterations of net interest income, and size toward share expected return in the banking company at BEI. In this study 14 samples of company available from industrial banking based ICMD 2010 during the period of 2006-2010 were analysed. Multiple linear regresion models was employed to test influence of net interest income and size toward share expected return. Result of classic assumption test abnormal distribution data showed no finding of any multi-collinear, heteroscedasticity, and autocorrelation. However the result showed share expected return was influenced simultaneuosly by PBB iteration, and size and partially no variable significantly influence expected return.

\section{PENDAHULUAN}

Setiap perusahaan tentunya membutuhkan dana untuk dapat mengelola dan mengembangkan usahanya. Salah satu cara untuk memperoleh dana tersebut adalah dengan menghimpun dana masyarakat, yakni dengan cara menerbitkan surat berharga seperti saham. Agar kegiatan penghimpunan dana tersebut lancar, maka dibutuhkanlah suatu wadah perantara atau intermediasi yang dikenal sebagai pasar modal. Dalam melakukan investasi di pasar modal, khususnya di pasar saham, investor harus memiliki pemahaman dan analisis yang sangat baik karena pasar saham memiliki tingkat ketidakpastian yang tinggi. Situasi ketidakpastian ini mendorong investor yang rasional untuk selalu mempertimbangkan risiko dan expected return setiap sekuritas. Risiko dan expected return tersebut dapat dinilai berdasarkan informasi kualitatif maupun kuantitatif (Kurniawan, 2000).

Pada saat seorang investor melakukan analisis terhadap perusahaan target investasinya, ia dapat menggunakan berbagai sumber informasi baik yang bersifat historis maupun aktual. Pada umumnya, investor menggunakan datadata historis dalam membuat suatu estimasi. Salah satu bentuk data historis adalah laporan keuangan perusahaan. Investor sangat bergantung pada laporan keuangan yang menyediakan data keuangan utama mengenai perusahaan (Jones, 2004). 


\begin{abstract}
Laporan keuangan sebagai sumber informasi utama dari suatu perusahaan memegang peranan penting bagi investor untuk melakukan analisis risiko dan expected return dari sumber daya yang diinvestasikannya.
\end{abstract}

Laporan laba rugi mencakup banyak angka laba, yang terdiri dari laba kotor, laba operasi dan laba bersih. Laba kotor dilaporkan lebih awal dari laba operasi, sedangkan laba operasi dilaporkan sebelum laba bersih. Artinya perhitungan angka laba kotor akan menyertakan lebih sedikit komponen pendapatan dan biaya dibandingkan dengan laba operasi; dan perhitungan laba operasi juga menyertakan lebih sedikit komponen pendapatan dan biaya dibandingkan dengan perhitungan laba bersih (Daniati dan Suhairi, 2006).

Menurut FASB, fokus utama pelaporan keuangan adalah informasi tentang kinerja perusahaan melalui pengukuran pendapatan dan komponenkomponennya. Semakin tinggi pendapatan bunga bersih yang dapat diperoleh oleh suatu bank maka semakin baik bank tersebut dalam menjalankan fungsi intermediasinya (waspada online, 23 Februari 2008). Menurut Huizinga (2000) seperti yang dikutip dalam Arsani (2004), pendapatan bunga bersih yang juga dapat dilihat dari rasio net interest margin mencerminkan pendapatan inti yang diperoleh Bank dari fungsi intermediasi. Selain itu, pendapatan bunga bersih juga mencerminkan tingkat efisiensi perbankan karena memperlihatkan selisih antara tingkat bunga kredit yang harus dibayarkan peminjam kepada bank atas pinjaman yang dilakukannya dengan tingkat bunga simpanan yang diterima atas balas jasa dari simpanannya di bank, sedang menurut Ridwan S. Suadjaja dan Inge Berlian (2003) melihat ukuran perusahaan berdasarkan sumber pembiayaannya (Bambang, 2005). Perusahaan besar adalah perusahan dengan sumber pembiayaan relatif luas dan perusahaan kecil, cenderung memiliki sumber pembiayaan terbatas.

Sementara George Foster (1993:98), menyatakan bahwa penjualan salah satu alat ukur yang dapat digunakan untuk mengendalikan efek yang berasal dari perbedaan ukuran perusahaan. Alat ukur yang dapat digunakan adalah total asset, modal pemegang saham, kapitalisasi pasar dan jumlah karyawan (Bambang, 2005).

Selain mempertimbangkan informasi keuangan keputusan investor juga dipengaruhi ukuran perusahaan. Perusahaan yang berukuran besar lebih mendapat perhatian media sehingga informasi yang disampaikan kepada para investor lebih mudah dan menjanjikan, sedangkan perusahaan kecil cenderung memiliki informasi dan sistem pengawasan yang lemah, sehingga kurang diperhatikan oleh pemegang sahamnya. ha. Berdasarkan uraian diatas, tujuan penelitian ini adalah untuk melihat pengaruh perubahan pendapatan bunga bersih, dan size perusahaan terhadap tingkat return saham yang diharapkan (expected return) oleh investor. Berdasarkan latar belakang masalah di atas, maka pokok masalah yang akan diambil sebagai berikut:

1. Apakah perubahan pendapatan bunga bersih berpengaruh terhadap expected return saham?

2. Apakah perubahan size perusahaan berpengaruh terhadap expected return saham?

3. Apakah perubahan pendapatan bunga bersih dan perubahan size perusahaan secara bersama - sama mempunyai pengaruh yang signifikan terhadap expected return saham?

\section{METODOLOGI}

Obyek pnelitian ini adalah perusahaan perbankan yang terdaftar di BEI periode 2006 - 2010. Pengambilan 
sampel dalam penelitian ini menggunakan purposive sampling (Tabel 1). Teknik analisis data menggunakan regresi berganda dengan bantuan software SPSS 16.0. Uji Asumsi Klasik (Normalitas, Multikolinieritas, Heteroskedastisitas, dan Autokorelasi) digunakan untuk memastikan data layak digunakan. Uji $\mathrm{F}$ digunakan untuk menilai kelayakan model serta Uji t untuk menguji signifikansi varibel independen.

Tabel 1. Daftar Perusahaan Perbankan yang lolos dalam seleksi sampel

\begin{tabular}{|l|l|l|}
\hline No & \multicolumn{1}{|c|}{ Emiten } & Kode \\
\hline 1 & Bank Central Asia Tbk & BBCA \\
\hline 2 & $\begin{array}{l}\text { Bank Rakyat Indonesia } \\
\text { (Persero) Tbk }\end{array}$ & BBRI \\
\hline 3 & $\begin{array}{l}\text { Bank Negara Indonesia } \\
\text { (Persero) Tbk }\end{array}$ & BBNI \\
\hline 4 & Bank Danamon Tbk & BDMN \\
\hline 5 & $\begin{array}{l}\text { Bank CIMB Niaga (d/h Bank } \\
\text { Niaga) Tbk }\end{array}$ & BNGA \\
\hline 6 & $\begin{array}{l}\text { Bank Pan Indonesia (Panin } \\
\text { Bank) Tbk }\end{array}$ & PNBN \\
\hline 7 & Bank Permata Tbk & BNLI \\
\hline 8 & Bank Mega Tbk & MEGA \\
\hline 9 & Bank Bukopin & NISP \\
\hline 10 & Bank NISP Tbk & INPC \\
\hline 11 & $\begin{array}{l}\text { Bank Artha } \\
\text { Internasional Tbk }\end{array}$ & $\begin{array}{l}\text { BABP } \\
\text { Tbk BumiPutera Indonesia }\end{array}$ \\
\hline 13 & Bank Mayapada Tbk & MAYA \\
\hline 14 & Bank Bumi ArtaTbk & BNBA \\
\hline
\end{tabular}

ISI

Dari penelitian didapatkan hasil perhitungan sebagai berikut:

1. Rata-rata Expected return Saham adalah 0,0301376 (dalam rentang dari 0,00292 hingga 0,25531 dan standar deviasi 0,06527997). Hal ini menunjukkan bahwa rata-rata tingkat expected return saham perbankan di
Indonesia cukup tinggi tetapi pergerakan return saham harian yang relatif tinggi.

2. Rata-rata perubahan pendapatan bunga bersih (PBB) adalah 0,1738588 (dalam rentang dari $-0,99894$ hingga 0,96111 dan standar deviasi 0,28191932). Standar deviasi yang relatif cukup menunjukan pola perubahan pendapatan bunga bersih (PBB) antar perusahaan perbankan cukup beragam.

3. Rata-rata perubahan size (size) adalah .3015428 (dalam rentang dari .01060 hingga 2.83051 dan standar deviasi .49585565). Hasil ini menunjukkan bahwa secara rata-rata perusahaan dalam sampel penelitian memiliki kemampuan untuk menghasilkan arus kas investasi sebesar .3015428. Standar deviasi yang cukup menunjukan perbedaan size antar perusahaan perbankan relatif cukup beragam.

Dari hasil uji normalitas diperoleh nilai asymptotic significant dari unstandardized residual sebesar 0,000 berada dibawah 0,05 , yang berarti bahwa model regresi tidak memenuhi asumsi normalitas namun dikarenakan jumlah sampel data besar $\mathrm{N}>30$ maka kemungkinan data tidak terpengaruh dan tetap berdistribusi

Berdasarkan hasil pengujian gejala multikolinieritas dapat dilihat bahwa semua variabel independent dan variabel pengendali yang digunakan menghasilkan nilai VIF lebih kecil dari 10 dan nilai Tolerance yang lebih dari 0.10 maka dapat disimpulkan bahwa tidak terdapat gejala multikoliniearitas. Dengan jumlah observasi sebanyak 14 dan variabel independen sebanyak dua variabel , maka dari uji DurbinWatson akan diperoleh nilai batas atas $\left(\mathrm{d}_{\mathrm{U}}\right)$ $=1,8493$ dan batas bawah $\left(\mathrm{d}_{\mathrm{L}}\right)=1,1891$ dengan nilai DW-hitung sebesar 2,476. Dari perhitungan tersebut dihasilkan nilai 4 -du $\leq \mathrm{d} \leq 4$-dl, yaitu 2,1507 < 
$2,476<2,8109$ sehingga keputusan yang diambil dengan hipotesis

nol yaitu tidak ada kepastian autokorelasi (ragu-ragu ).

Salah satu metode untuk mendeteksi adanya heteroskedastisitas adalah dengan membuat scatter-plot antara standardized Residual (ZRESID) dan Standardized Predicted Value (Y topi). Pada Gambar 1 menunjukkan tidak ada perubahan nilai residual sepanjang Y maka dinyatakan tidak ada heteroskedastisitas pada galat (error/ residual) tersebut.

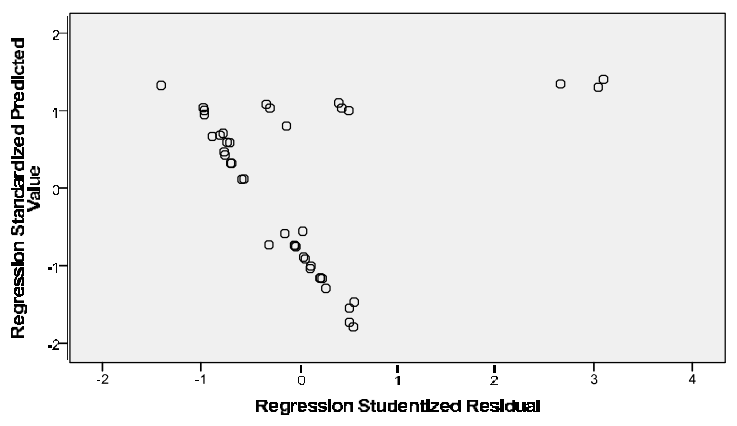

Gambar 1. Uji Gejala Heteroskedastisitas

Pengujian terhadap hipotesis penelitian bertujuan untuk mengetahui apakah komponen pendapatan bunga bersih dan size dapat mempengaruhi expected return sahampada perusahaan perbankan.

\section{Uji F ( Uji Signifikansi Model)}

Hasil estimasi SPSS atas uji signifikasi keseluruhan model (Uji F) diketahui bahwa probabilitas distribusi $\mathrm{F}$ atas model penelitian ini adalah sebesar 0,041 (significance level) $5 \%$ (Tabel 2), probabilitas distribusi $\mathrm{F}$ model penelitian diatas lebih kecil dari tingkat keyakinan yang berarti bahwa $\mathrm{H}_{0}$ ditolak. Hal ini menunjukkan expected return saham dipengaruhi secara bersama-sama oleh perubahan Pendapatan Bunga Bersih dan perubahan size Hasil ini juga menunjukkan bahwa model ini dapat digunakan. Dari Tabel 3 dapat dilihat bahwa pengolahan data yang dilakukan menghasilkan nilai $\mathbf{R}_{\text {square }}$ sebesar 0,299 atau 29,9\%. Nilai $\mathrm{R}_{\text {square }}$ sebesar $29,9 \%$ menunjukkan bahwa variabel-variabel independen utama di dalam penelitian ini, yaitu perubahan Pendapatan Bunga Bersih, dan perubahan size mampu menjelaskan variabel bebas Expected return saham perbankan tahun 20072010. Sedangkan sisanya sebanyak $70,1 \%$ dijelaskan oleh faktor-faktor lain di luar model penelitian. Nilai $\mathrm{R}_{\text {square }}$ tersebut sangat rendah, namun untuk penelitian di bidang Akuntansi nilai tersebut sudah termasuk wajar.

\begin{tabular}{|c|c|c|c|c|}
\hline Model & $\begin{array}{c}\text { Sum of } \\
\text { Square } \\
\text { S }\end{array} \mid$ & df & $\begin{array}{c}\text { Mean } \\
\text { Square }\end{array}$ & $F$ \\
\hline $\begin{array}{l}1 \text { Regress } \\
\text { ion }\end{array}$ & .052 & 6 & .009 & $\begin{array}{r}2.49 \\
2\end{array}$ \\
\hline $\begin{array}{l}\text { Residua } \\
1\end{array}$ & .122 & 35 & .003 & \\
\hline Total & .175 & 41 & & \\
\hline
\end{tabular}

Tabel 3. Koefisien Determinasi

\begin{tabular}{|c|c|c|c|c|c|}
\hline $\begin{array}{l}\text { Mode } \\
1\end{array}$ & $\mathrm{R}$ & $\begin{array}{c}\mathrm{R} \\
\text { Squa } \\
\text { re }\end{array}$ & $\begin{array}{l}\text { Adjusted } \\
\text { R Square }\end{array}$ & $\begin{array}{l}\text { Std. Error } \\
\text { of the } \\
\text { Estimate }\end{array}$ & $\begin{array}{l}\text { Durbin- } \\
\text { Watson }\end{array}$ \\
\hline 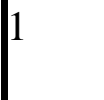 & $.547^{\circ}$ & 299 & .179 & .0591429 & 2.476 \\
\hline
\end{tabular}

a. Predictors: (Constant), SIZE, PBB

\section{Uji t (Uji Signifikasi Variabel)}

Tabel 4 berikut ini menyajikan hasil estimasi koefisien konstanta dan seluruh variabel independennya. Tabel 3 juga menyajikan hasil uji t untuk setiap koefisien variabel independen tersebut.

Berdasarkan Tabel 4 yang diperoleh dari hasil uji regresi berganda, pembahasan mengenai pengujian hipotesis penelitian sebagai berikut : 
Tabel 4. Hasil Uji t.

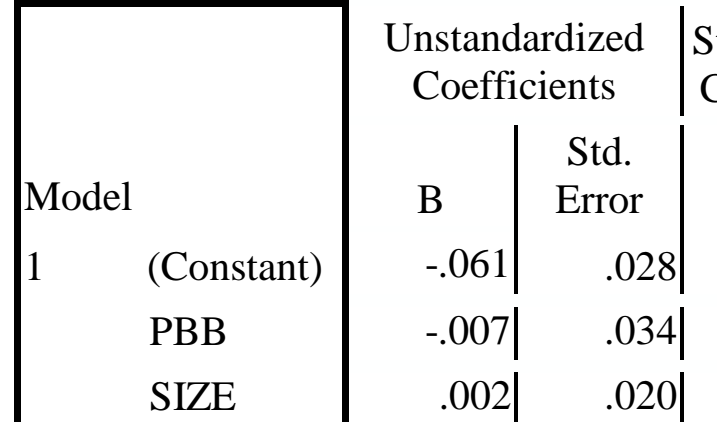

a. Hasil uji parsial menunjukkan bahwa perubahan Pendapatan Bunga Bersih tidak memiliki pengaruh yang signifikan baik pada $=1 \%$, $5 \%$, maupun 10\%. Signifikansi variabel perubahan Pendapatan Bunga Bersih adalah 0,837, dengan hasil itu maka H0 tidak dapat ditolak. Walaupun tidak signifikan, tanda koefisien variabel Pendapatan Bunga Bersih (PBB) ini menunjukkan tanda negatif, yang memberikan indikasi lemah bahwa pendapatan bunga bersih (PBB) perusahaan perbankan memiliki pengaruh negatif dengan expected return saham.

b. Variabel SIZE tidak berpengaruh terhadap expected return saham baik pada $1 \%, 5 \%$, maupun $10 \%$.

\section{Model Regresi Yang Terbentuk}

Berikut ini disajikan hasil regresi yang menunjukkan koefisien dari masing-masing variabel independen dan variabel pengendali. Berdasarkan hasil pengujian yang telah dilakukan model regresi yang terbentuk adalah sebagai berikut:

\section{$Y_{\text {it }}=-0,061-0,007 \quad \Delta$ PBB $_{t} / \mathbf{P B B}_{(\mathrm{t}-1)}+$ $0,002 \Delta$ SIZE $_{t} /$ SIZE $_{i(t-1)}$}

Keterangan:

$\mathrm{Y}$ it $=$ Expected return saham perusahaan I pada periode $\mathrm{t}$

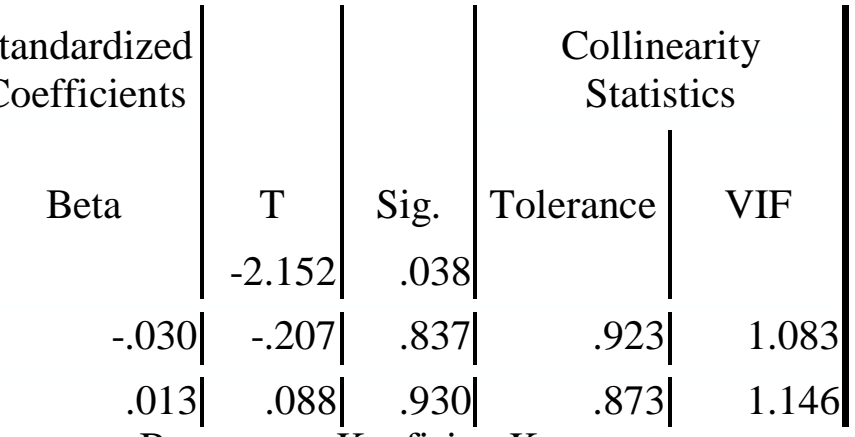

Bo = Koefisien Konstanta

B 1-5 = Koefisien regresi variabel independent

$\begin{aligned} \Delta \mathrm{PBB}_{\mathrm{t}}= & \underset{\text { Pendapatan Bunga }}{ } \begin{array}{r}\text { Bersih } \\ \text { periode } \mathrm{t}\end{array} \\ & \text { perusahaan pada }\end{aligned}$

$\Delta \mathrm{SIZE}_{\mathrm{t}}=$ Size perusahaan pada periode $\mathrm{t}$

Penjelasan dari model regresi

yang terbentuk adalah sebagai berikut:

Koefisien variabel Perubahan Pendapatan

Bunga Bersih (PBB)

1. sebesar -0.007 tidak berpengaruh terhadap expected return saham baik pada $1 \%, 5 \%$, maupun $10 \%$.

2. Koefisien Variabel Perubahan SIZE sebesar $0,002 \quad$ menunjukkan pengaruh positif dengan expected return saham, namun hasil uji parsial menunjukkan bahwa tidak cukup bukti variabel Perubahan SIZE memiliki pengaruh yang signifikan terhadap expected return saham baik pada $=1 \%, 5 \%$, maupun $10 \%$.

Berdasarkan hasil-hasil yang telah diuraikan diatas, maka diperoleh beberapa pokok hasil penelitian sebagai berikut:

1. Expected return saham dipengaruhi secara bersama-sama oleh perubahan Pendapatan Bunga Bersih, dan perubahan Size sebagai variabel utama penelitian. Hal ini membuktikan bahwa hipotesis 3 
tidak terbukti.

2. Koefisien variabel perubahan pendapatan bunga bersih (PBB) menunjukkan arah negatif terhadap expected return saham yang berarti semakin tinggi perubahan pendapatan bunga bersih (PBB) dalam suatu perusahaan maka Akan menurunkan expected return saham namun secara statistic hasil penelitian menunjukkan bahwa perubahan pendapatan bunga bersih (PBB) tidak berpengaruh signifikan terhadap expected return saham. Hasil penelitian ini tidak mendukung hipotesis $\mathrm{H} 1$ dan berbeda dengan penelitian Jogiyanto (2000) dan Dillah (1999). Arah pengaruh yang negatif sesuai dengan penelitian Febrianto (2005) yang menyatakan bahwa pasar di Indonesia bereaksi negatif terhadap angka laba yang diumumkan oleh perusahaan.

3. Perubahan size perusahaan berpengaruh positif tidak signifikan terhadap expected return saham secara parsial. Hasil penelitian ini tidak sesuai dengan hipotesis $\mathrm{H} 2$ dimana size perusahaan berpengaruh negative signifikan terhadap expected return saham yang berarti perusahaan kecil mempunyai expected return saham yang lebih tinggi dibandingkan perusahaan besar. Hasil ini sejalan dengan penelitian Ninna Daniati (2006) dan Miswanto (1999).

\section{PENUTUP}

Berdasarkan hasil penelitian ini maka

1. Expected return saham dipengaruhi secara bersama-sama oleh perubahan Pendapatan Bunga Bersih, dan perubahan Size.

2. Tidak cukup bukti bahwa perubahan pendapatan bunga bersih berpengaruh signifikan terhadap expected return saham.

3. Tidak cukup bukti bahwa perubahan size berpengaruh signifikan terhadap expected return saham.

Penelitian ini tidak berhasil menemukan adanya pengaruh perubahan pendapatan bunga bersih (PBB) dan SIZE terhadap expected return saham selama periode pengamatan mungkin disebabkan oleh variabel perubahaan pendapatan bunga bersih (PBB) dan SIZE merupakan komponen basi yang telah diantisipasi oleh pasar sebelum diumumkan .Linda (2005) menyatakan bahwa variabel variabel yang telah diantisipasi oleh pasar sebelum diumumkan merupakan komponen basi sehingga kurang relevan dalam menjelaskan return saham.

Karena data akuntansi bersifat historical cost dan konservatif maka penggunaan model linier kemungkinan kurang tepat. Pervin Shroff (2007) menunjukkan sifat konservatif dalam data akuntansi mendorong adanya pengaruh non-linier karena laba lebih cepat dalam menangkap informasi yang buruk dibandingkan informasi yang baik. Hal ini menyebabkan kemampuan untuk menjelaskan dan koefisien estimasi dari model return linier kurang bermanfaat dibandingkan dengan spesifikasi model return yang non-linier.

\section{DAFTAR PUSTAKA}

Ali, Ashig. 1994. The Incremental Information Content of Earnings, Working Capital from Operation and Cash Flows. Journal of Accounting Research. Vol. 32 No 1 (Spring): 61-67.

Anggono, Alexander. 2002. Relevansi Peramalan dan Relevansi Nilai Komponen Laba. Simposium Nasional Akuntansi V Semarang. 
DI BEI TAHUN 2006 - 2010

Arsani, Komang Srie. 2004. Analisis Pengaruh Indikator Makro ekonomi Terhadap ProfitabilitasPerbankan. Jakarta: Magister Manajemen Fakultas Ekonomi Universitas Indonesia

Bathke,Wallen, Kenneth S Lorek and G Lee Willinger (1989), Firm Size and the Prediction of Future Cash Flows, The Accounting Review, Vol LXIV, No. 1 : 4969.

Birngham, Eugene F, and Joel, F Houston (2001), Intermediate Financial Management, Eight Edition, London : South Western Thompson Learning : 104.

Clarkson, P., Guedes, J. And Thompson, R. (1996), On the Diversification, Observability, and Measurement of Estimation Risk, Journal of Financial and Quantitative Analysis, vol. 31 (1), pp. 69-84.

Coles, J. L., Loewenstein, U. \& Suay, J. (1995), On Equilibrium Pricing under Parameter Uncertaintiy, Journal of Financial and Quantitative Analysis, vol. 30 (3), hal. 347364.

Daniati, Ninna dan Suhairi. 2006. Pengaruh Kandungan Informasi Komponen Laporan Arus Kas, Laba Kotor, dan Size Terhadap Expected Return

Saham (Survey Pada Industri Tekstil dan Automotive yang Terdaftar Di BEJ), Simposium Nasional Akuntansi IX Padang.

Diyanti, Vera. 2000. Analisa Pengaruh Laba Bersih dan Arus Kas Terhadap Return Saham. Jakarta: Magister Manajemen Fakultas Ekonomi Universitas Indonesia
Febrianto, Rahmat \& Erna Widiastuty. 2005. Tiga Angka Laba Akuntansi: Mana yang Lebih Bermakna Bagi Investor?, Simposium Nasional Akuntansi VIII Solo.

Ferry dan Erna Eka Wati. 2004. Pengaruh Informasi Laba, Aliran Kas dan Komponen Aliran Kas Terhadap Harga Saham pada Perusahaan Manufaktur di Indonesia. Simposium Nasional Akuntansi VII (Denpasar): 1122-1133.

Foster, George (1993), Financial Statement Analysis, Third Edition, New Jersey : Prentice Hall International, Inc : 98.

Handa, P. \& Linn, S. C. (1993), Arbitrage Pricing with Estimation Risk, Journal of Financial and Quantitative Analysis, vol. 28 (1), hal. 81-100. Hartono, Jogiyanto. 2003. Teori Portofolio dan Analisis Investasi. Edisi Ketiga. Yogyakarta: Badan Penerbit Fakultas Ekonomi Universitas Gadjah Mada.

Huizinga, Kunt. 2000. Financial Structure and Bank Profitability. The World Bank Development Group Finance Working Paper.

Ikatan Akuntan Indonesia (IAI). 2009.

Pernyataan Standar Akuntansi Keuangan. Jakarta: Salemba Empat.

Julyn (2005), Skripsi : Praktik Perataan Laba dan Faktor - Faktor yang Mempengaruhinya, IBII, Jakarta (tidak dipublikasikan).

Jones, Charles P. 2004. Investment: Analysis and Management. $9^{\text {th }}$ Edition. United States of America: John Willey \& Sons, Inc.

Keputusan Ketua Badan Pengawas 
Pasar Modal. Kep-06/PM/2000 Tentang Perubahan Peraturan Nomor VIII.G.7 Tentang Pedoman Penyajian Laporan Keuangan.

Kieso, Donald E. and Jerry J. Weygandt. 2005. Intermediate Accounting. $11^{\text {th }}$ Edition. New York: John Willey \& Sons, Inc.

Kurniawan, Heribertus dan Nur Indriantoro. 2000. Analisis Hubungan Antara Arus Kas Dari Aktivitas Operasi dan Data Akrual Dengan Return Saham: Studi Empiris Pada Bursa Efek Jakarta. Jurnal Bisnis dan Akuntansi. Vol 2 No.3 (Desember) : 207-224.

Livnat $\mathrm{J}$ and $\mathrm{P}$. Zarowin. 1990. The Incremental Information Content of Cash Flows Components. Journal of Accounting and Economics. Vol.13 : 25-46.

Lawrence J. Gitman (2006), Principle Of Managerial Finance, Eleventh Edition, Boston : Pearson Educational, Inc : 45 - 46, 102 124, 329 - 338.

Miller, Merton and Kevin Rock. 1985. Dividend Policy Under Asymmetric Information. Journal of Finance 4 : 1031-1052.

Nurmalia, Kartika. 2007. Analisa Hubungan Informasi Akrual, Arus Kas dan Dividen Dalam Laporan Keuangan Emiten Bursa Efek Jakarta Periode 2001-2005 Dengan Ekspektasi Laba Masa Depan dan Imbal Hasil Saham Masa Depan. Depok : Fakultas Ekonomi Universitas Indonesia.

Novi Indriana Soepratikno dan Jogiyanto Hartono (2005). Pengaruh Atribut Perusahaan Terhadap Relevansi Laba dan Arus kas. Jurnal Riset Akuntansi Indonesia. Vol 8 No 3 (September).
Philips, G. Edward \& Lucille S. Mayne. 1970. Income Measures and Bank Stock Values. Journal of Accounting Research, Vol. 8, Empirical Research in Accounting: Selected Studies, pp. 178-188.

Ridwan S. Sandjaja dan Inge Berlian (2003), Manajemen Keuangan II, Edisi 4, Jakarta : Literata Lintas Media.

Ross, et.al. 1995. Fundamentals Of Cor porate Finance. $3^{\text {rd }}$ Edition. United States of America: Irwin.

Scott, W.R. 2000. Financial Accounting Theory, 2nd edition. Prentice Hall Canada Inc.

Siegel, J. G., \& Shim, J. K. 1994. Kamus Istilah Akuntansi. Jakarta: PT. Elex Media Computindo, Kelompok Gramedia.

Sinaga, Ronald. 1992. Peranan Informasi Akuntansi Terhadap Pembentukan Harga Saham Sektor Perbankan di Pasar Modal: Studi Kasus Bursa Efek Jakarta. Jakarta: Fakultas Ekonomi Universitas Indonesia.

Stanga, G. Keith. 1976. Disclosure in Published Annual Reports. Financial Management, Vol. 5, No. 4. (Winter, 1976), pp. 42-52.

Sutopo, Bambang. 2002. Earningsprice ratio dan kandungan informasi arus kas. Perspektif vol.7 no. 2 .

Swaminathan, Siva \& Joseph Weintrop. $1991 . \quad$ The Information Content of Earnings, Revenues and Expenses. Journal of Accounting Research, Vol. 29 No. 2. pp. 418426.

Tjiptono Darmadji dan Hendi $M$. Fakhruddin (2001), Pasar Modal di Indonesia, Jakarta : Penerbit 
Salemba Empat.

Triyono dan Jogiyanto Hartono. 2000.

Hubungan Kandungan Informasi

Arus Kas, Komponen Arus Kas dan Laba Akuntansi dengan Harga dan Return Saham. Jurnal Riset Akuntansi Indonesia. Vol. 3 No. 1 (Januari):

54-68.

Wardiyanti, Francisca Olivine. 2006.

Analisa Hubungan Tingkat

Pengungkapan Laporan Tahunan

Terhadap Biaya Modal Perusahaan

dengan Likuiditas Sebagai

Variabel pengendali dan

Solvabilitas Serta Ukuran Perusahaan Sebagai Variabel pengendali dan Variabel Moderasi Pada Industri Perbankan dan Lembaga Keuangan Non Bank di Indonesia. Jakarta: Magister Akuntansi Fakultas Ekonomi Universitas Indonesia.

Zvi Bodie, Alex Kane and Alan J. Marcus (2005), Investments, Sixth Edition, New York : Mc Graw-Hill Companies. 